IJMS 17 (1), 171-188 (2010)

\title{
HUBUNGAN PEMBANGUNAN INDUSTRI PELANCONGAN DAN PERTUMBUHAN EKONOMI DI BEBERAPA NEGARA UTAMA ASEAN
}

\author{
REDZUAN OTHMAN \\ NORLIDA HANIM MOHD SALLEH \\ Fakulti Ekonomi dan Perniagaan \\ Universiti Kebangsaan Malaysia
}

\begin{abstract}
ABSTRAK
Makalah ini bertujuan mengkaji corak hubungan antara pembangunan ekonomi dengan pertumbuhan industri pelancong di beberapa negara utama ASEAN iaitu Malaysia, Thailand, Singapura dan Indonesia. Khususnya kajian cuba menguji hipotesis sama ada perkembangan industri pelancongan sebagai perangsang kepada pertumbuhan ekonomi (tourism-led economic growth - (TLG) atau pertumbuhan ekonomi sebagai perangsang kepada perkembangan industri pelancongan (economic growth-led tourism - GLT). Bagi tujuan tersebut, analisis ekonometrik yang menggunakan kaedah ujian kointegrasi dan penyebab Granger digunakan. Hasil kajian mendapati wujud hubungan satu hala antara perkembangan industri pelancongan dengan pertumbuhan ekonomi. Bagi negara Thailand dan Indonesia didapati pertumbuhan ekonomi sebagai penyebab kepada perkembangan industri pelancongan (GLT), sementara bagi Malaysia dan Singapura pula perkembangan industri pelancongan adalah penyebab kepada pertumbuhan ekonomi (TLG). Makalah ini mengaplikasikan teori dan realiti iaitu, penggunaan pendekatan penyebab Granger dalam menganalisis realiti industri pelancongan dan pertumbuhan ekonomi.
\end{abstract}

Kata kunci: Pertumbuhan ekonomi; pembangunan industri pelancongan; ujian kointegrasi; penyebab granger.

\begin{abstract}
Purpose - This study investigated the pattern of relationship between the development of tourism industry and the economic growth in major ASEAN countries namely Malaysia, Thailand, Singapore, and Indonesia. More specifically,
\end{abstract}


this study tested hypotheses whether tourism development is a cause for economic growth (tourism-led economic growth-TLG) or the economic growth is a cause for tourism development (economic growth led tourism - GLT).

Design/Methodology/Approach - An econometric analysis which applied the cointegration test and Granger causality analysis was employed to clarify these issues.

Findings - Results of the study had shown that there is only a one-way relationship between tourism development and economic growth in these countries. For Thailand and Indonesia economic growth is the leading factor for tourism development (GLT) whereas in Malaysia and Singapore, tourism development is the leading factor for economic growth (TLG).

Originality/Value - This paper investigate whether tourism-led economic growth - TLG) or the economic growth led tourism development-GLT). It is important especially for the policy makers since it can give some ideas to further develop economic growth as well as the tourism industry.

Keywords: Economic growth; tourism development; cointegration; granger causality.

\section{Pengenalan}

Industri pelancongan yang berkembang berabad yang lalu didapati berjaya menjadi sumber penjana pendapatan wang asing yang tinggi. Ini terbukti dengan peningkatan pendapatan daripada pelancongan semasa. Pada tahun 1950 pendapatan pelancongan antarabangsa bernilai sekitar US\$2.1 bilion. Perolehan ini meningkat kepada US\$622.7 bilion pada tahun 2004. Ini bermakna dalam tempoh 54 tahun pendapatan daripada pelancongan antarabangsa telah meningkat pada kadar purata melebihi 11\% setahun.

- Peningkatan ini ekoran daripada peningkatan aktiviti melancong dalam kalangan masyarakat terutama sejak kebelakangan ini. World Tourism Organization (WTO) menyatakan hanya terdapat sejumlah 25.3 juta lawatan antarabangsa sahaja dilakukan pada 1950. Bagaimanapun, menjelang tahun 2004 angka ini meningkat kepada lebih daripada 30 kali ganda iaitu sejumlah 763.2 juta ketibaan pelancong antarabangsa. Ini bermakna ketibaan pelancong antarabangsa meningkat sejumlah lebih daripada $6 \%$ setahun di sepanjang tempoh ini.

Satu perkara yang menarik tentang corak ketibaan ini adalah berdasarkan pasaran utama pelancongan. Dalam tempoh 54 tahun yang lalu didapati

172 IJMS 17 (1), 171-188 (2010) 


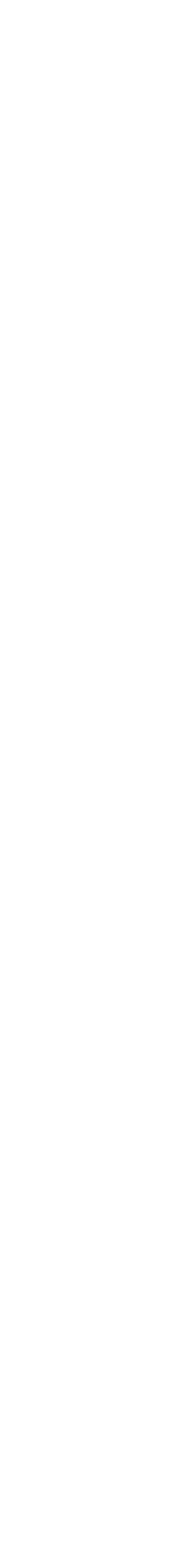

pasaran pelancongan yang telah kukuh seperti Amerika dan Eropah menunjukkan arah aliran peningkatan yang lebih rendah berbanding peratus purata peningkatan keseluruhan pasaran antarabangsa dan pasaran pelancongan baru seperti Afrika, Asia dan Pasifik serta Timur Tengah. Dalam tempoh ini pasaran Amerika dan Eropah masing-masing meningkat sebanyak $5.3 \%$ dan $6.1 \%$ berbanding dengan purata pertumbuhan keseluruhan dunia sebanyak $6.4 \%$. Manakala bagi pasaran pelancongan baru mengalami pertumbuhan yang lebih tinggi khususnya pasaran Asia dan Pasifik dengan kadar pertumbuhan tertinggi iaitu 12.5\% diikuti oleh pasaran Timur Tengah dan Afrika yang masing-masing sejumlah 9.9\% dan $8.0 \%$. Ciri yang agak ketara dalam konteks ketibaan pelancong di pasaran utama dunia ialah pertumbuhan pesat ketibaan pelancong ke pasaran yang baru terutamanya ke Asia dan Pasifik (WTO, 2006).

Peningkatan pesat dalam ketibaan pelancong antarabangsa ke pasaran baru khususnya ke pasaran Asia dan Pasifik disebabkan oleh minat pelancong untuk meneroka destinasi baru dengan produk pelancong yang baru khususnya produk berasas alam sekitar dan warisan sejarah. Kos melancong yang lebih murah turut menggalakkan kesampaian lebih ramai pelancong ke kawasan ini. Pada masa yang sama pihak kerajaan di kebanyakkan negara di rantau ini turut mengambil inisiatif untuk memajukan sektor pelancongan di negara masing-masing. Pelbagai strategi dan galakan diberikan kepada pengusaha pelancong terutama pengusaha swasta untuk merangsang pembangunan industri pelancongan mereka dengan menyediakan pelbagai kemudahan yang diperlukan oleh pelancong.

Di kawasan Asia dan Pasifik, rantau ASEAN merupakan antara destinasi yang menerima pelancong tertinggi selepas rantau Timur Jauh. Ini diikuti oleh rantau Australasia, Melanesia, Micronesia dan Polynesia. Berdasarkan Jadual 1 pada tahun 1990 rantau ASEAN menerima 21.5 juta pelancong daripada keseluruhan pelancong antarabangsa ke rantau Asia dan Pasifik. Jumlah ini meningkat kepada 37 juta pada tahun 2000, 66.7 juta pada 2010 dan 135.8 juta pada 2020. Dalam peratusan, rantau ASEAN menguasai sekitar 34-39\% daripada keseluruhan rantau Asia dan Pasifik. Perincian bahagian pasaran pelancong oleh negara-negara ASEAN pula adalah ditunjukkan oleh Jadual 2.

Daripada Jadual 2 jelas menunjukkan empat negara penerima pelancong asing utama adalah Malaysia, Thailand, Singapura dan Indonesia. Perangkaan menunjukkan Malaysia menguasai sekitar 25-35\% daripada pasaran ASEAN, diikuti oleh Thailand dengan peratusan sekitar 25\%, Singapura $17-23 \%$ dan Indonesia $10-15 \%$. Bahagian pasaran negara-negara lain daripada rantau ASEAN iaitu Brunei, Kemboja, Laos, Myanmar, Filipina dan Vietnam adalah kurang daripada 10\%.

IJMS 17 (1), 171-188 (2010) 


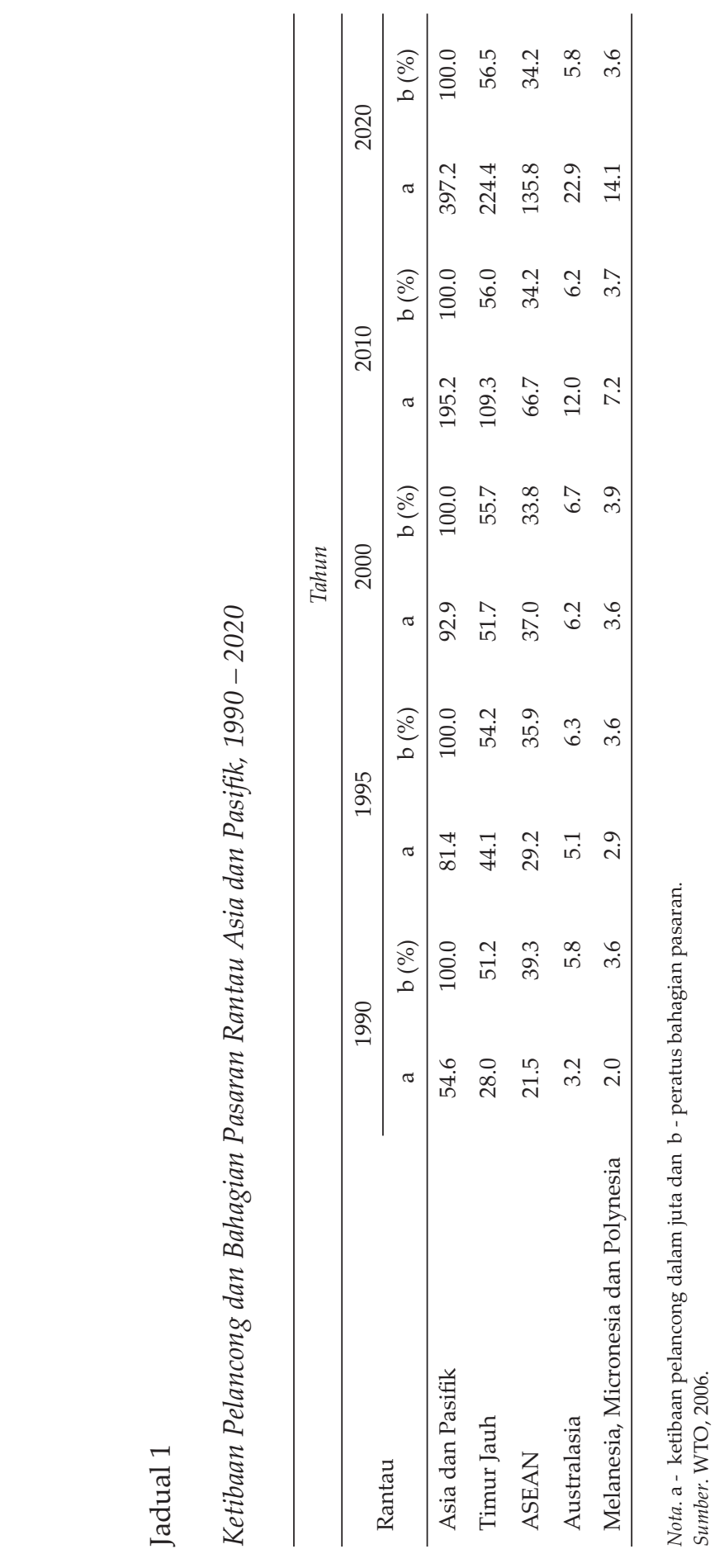

174 IJMS 17 (1), 171-188 (2010) 


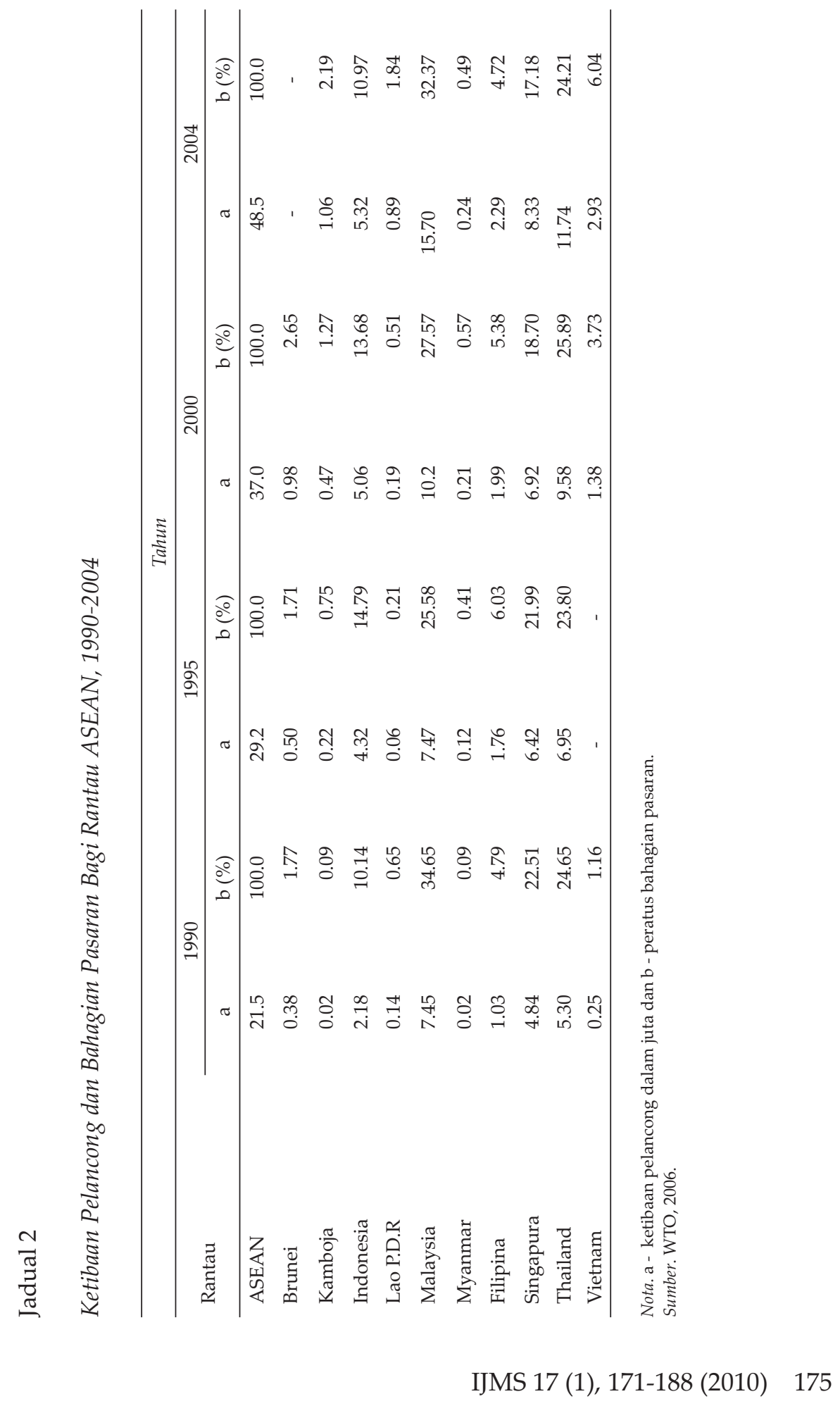


Corak ketibaan pelancong tahunan adalah seperti di Rajah 1 yang menunjukkan peningkatan bagi keempat-empat negara. Dalam konteks pertumbuhan purata tahunan, ketibaan pelancong ke Malaysia, Indonesia, Singapura dan Thailand antara tahun 1976-2005 masing-masing pada kadar $8.7 \%, 9.1 \%, 6.8 \%$ dan $8.8 \%$. Senario ini jelas menunjukkan berlakunya perkembangan industri pelancongan yang diproksikan oleh bilangan ketibaan.

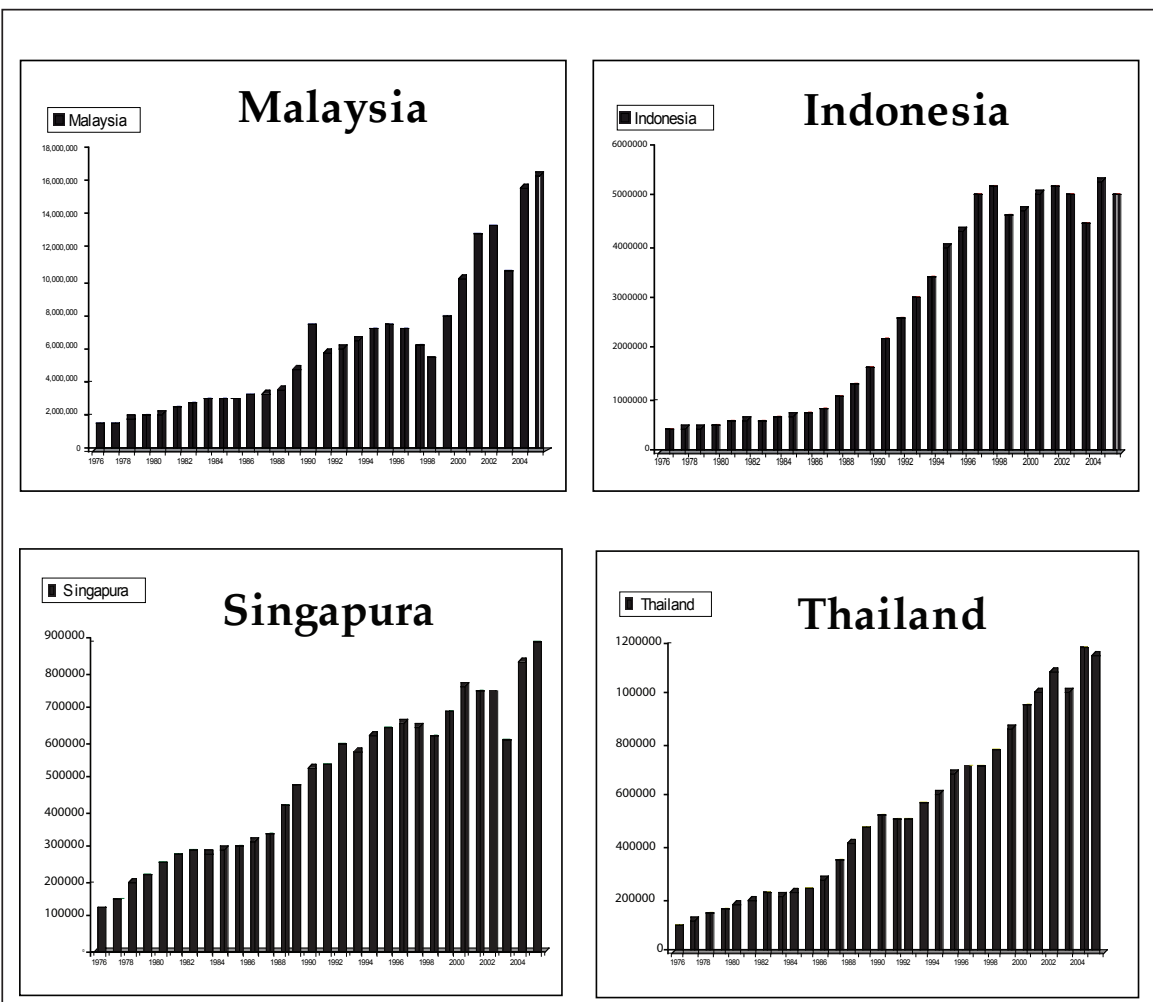

Rajah 1. Ketibaan Pelancong Antarabangsa bagi Malaysia, Indonesia, Singapura dan Thailand, $1976-2005$.

Pada masa yang sama, keempat-empat negara juga mencatatkan pertumbuhan ekonomi yang positif. Ini ditunjukkan oleh corak peningkatan KDNK seperti di Rajah 2. Lebih terperinci di dapati antara tahun 19762005, kadar pertumbuhan ekonomi purata tahunan yang dicatatkan oleh Malaysia, Indonesia, Singapura dan Thailand berkembang masing-masing pada kadar $8.7 \%, 5.7 \%, 7.1 \%$ dan $6.2 \%$. 

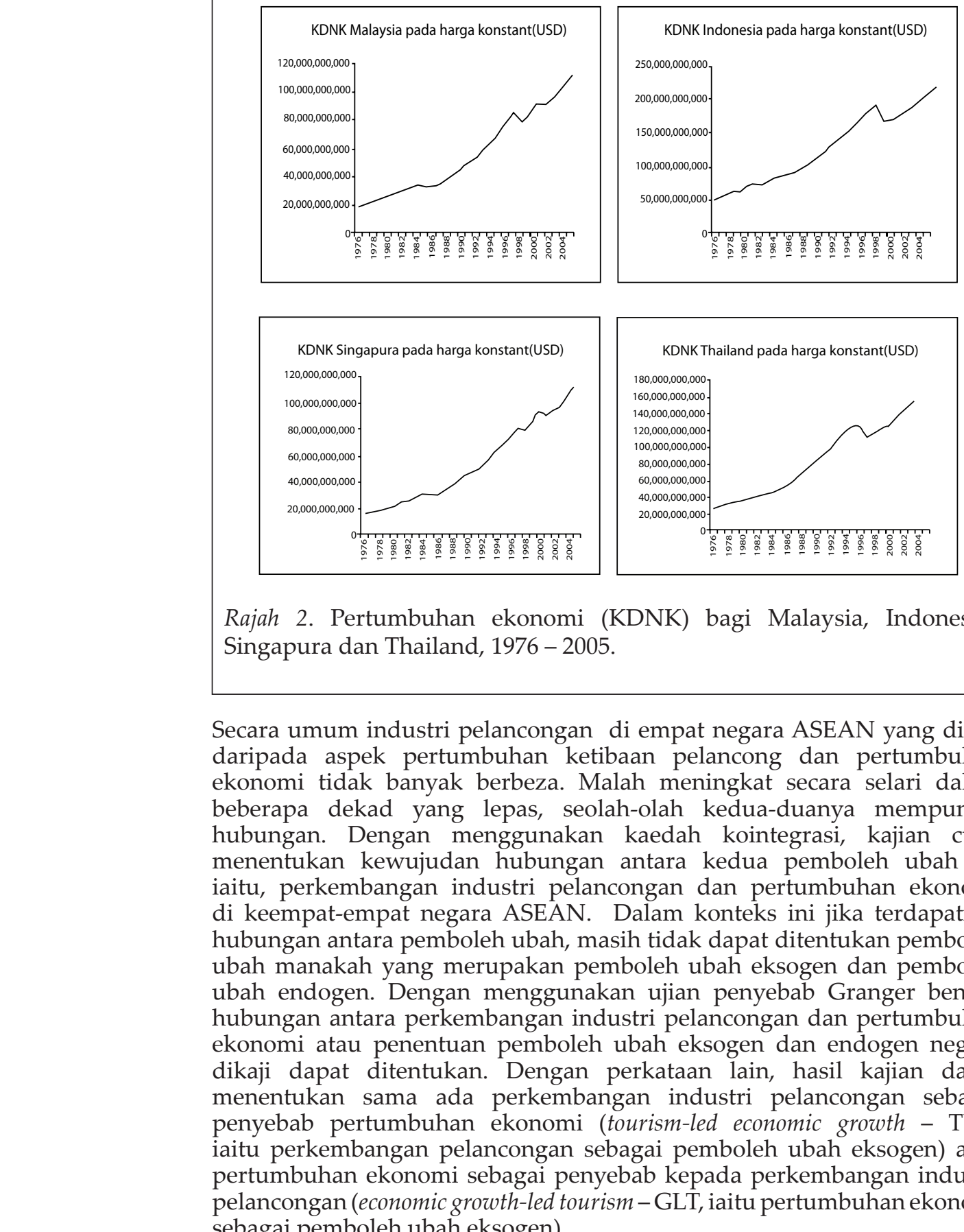

Rajah 2. Pertumbuhan ekonomi (KDNK) bagi Malaysia, Indonesia, Singapura dan Thailand, $1976-2005$.

Secara umum industri pelancongan di empat negara ASEAN yang dikaji daripada aspek pertumbuhan ketibaan pelancong dan pertumbuhan ekonomi tidak banyak berbeza. Malah meningkat secara selari dalam beberapa dekad yang lepas, seolah-olah kedua-duanya mempunyai hubungan. Dengan menggunakan kaedah kointegrasi, kajian cuba menentukan kewujudan hubungan antara kedua pemboleh ubah ini iaitu, perkembangan industri pelancongan dan pertumbuhan ekonomi di keempat-empat negara ASEAN. Dalam konteks ini jika terdapatnya hubungan antara pemboleh ubah, masih tidak dapat ditentukan pemboleh ubah manakah yang merupakan pemboleh ubah eksogen dan pemboleh ubah endogen. Dengan menggunakan ujian penyebab Granger bentuk hubungan antara perkembangan industri pelancongan dan pertumbuhan ekonomi atau penentuan pemboleh ubah eksogen dan endogen negara dikaji dapat ditentukan. Dengan perkataan lain, hasil kajian dapat menentukan sama ada perkembangan industri pelancongan sebagai penyebab pertumbuhan ekonomi (tourism-led economic growth - TLG, iaitu perkembangan pelancongan sebagai pemboleh ubah eksogen) atau pertumbuhan ekonomi sebagai penyebab kepada perkembangan industri pelancongan (economic growth-led tourism - GLT, iaitu pertumbuhan ekonomi sebagai pemboleh ubah eksogen). 


\section{Kajian Lepas}

Secara umumnya terdapat banyak kajian yang melihat pertalian kesan beberapa pemboleh ubah ekonomi kepada pertumbuhan ekonomi dan arah sebab penyebab antara pemboleh ubah terlibat. Antaranya adalah kesan eksport, perbelanjaan sektor kewangan dan pelaburan langsung asing kepada pertumbuhan ekonomi. Berikut beberapa hasil kajian oleh penyelidik berkaitan.

Kajian oleh Balassa (1977); Esfahani (1991); Dodaro (1993) dan Amaoeteng dan Amoaka (1996) mendapati galakan dalam eksport telah meningkatkan pertumbuhan ekonomi. Sementara kajian oleh Demetriades dan Hussein (1996); Murinde dan Eng (1994) dan Thornton (1997) mendapati pembangunan sektor kewangan menyokong kepada pertumbuhan ekonomi.

Dalam konteks perbelanjaan kerajaan pula hasil kajian agak berlainan antara pengkaji. Kajian Ram (1986) dan Grossman (2003) mendapati saiz perbelanjaan dan pertumbuhan ekonomi mempunyai hubungan langsung yang positif. Ghali (1998) pula mendapati terdapat hubungan penyebab antara perbelanjaaan kerajaan dengan pertumbuhan ekonomi di negara OECD. Manakala kajian Dalamagas (2000) di Greek mendapati keputusan yang sebaliknya iaitu, hubungan negatif antara kedua pemboleh ubah yang dikaji.

Dalam aspek pelaburan langsung asing, hasil kajian yang diperoleh antara pengkaji adalah tidak sama. Kajian Borensztein, Gregorio dan Lee (1998) tentang aliran pelaburan langsung asing ke 69 buah negara membangun mendapati pelaburan langsung asing merupakan sebagai kaedah penting kepada pemindahan teknologi dan membawa kepada pertumbuhan ekonomi negara terbabit. Dari segi hubungan sebab menyebab pula kajian Shan (2002) dan Liu, Burridge dan Sinclair (2002) mendapati terdapat hubungan dua hala antara pelaburan langsung asing dengan pertumbuhan output di China. Kajian oleh Mohd Azlan, Zulkefly dan Aminudin (2003) mendapati arah sebab penyebab antara pelaburan langsung asing dan pertumbuhan ekonomi antara negara maju dan negara sedang membangun adalah tidak selaras.

Dalam bidang pelancongan pula, walaupun kajian tentang kesan perkembangan industri pelancongan terhadap pertumbuhan ekonomi khususnya kajian impak industri ini kepada ekonomi melalui pendekatan input-output agak meluas, tetapi kajian yang lebih khusus melihat sebab penyebab antara kedua-duanya agak baru dan kurang terutamanya di negara sedang membangun. Kajian yang dibuat oleh Balaguer dan Cantavella-Jorda (2002) di Sepanyol mendapati perkembangan dalam pelancongan menjadi penyebab kepada pembangunan ekonomi dalam satu arah sahaja. Di Greece kajian oleh Dritakis (2005) pula menunjukkan terdapat dua arah penyebab antara perkembangan pelancongan dengan 


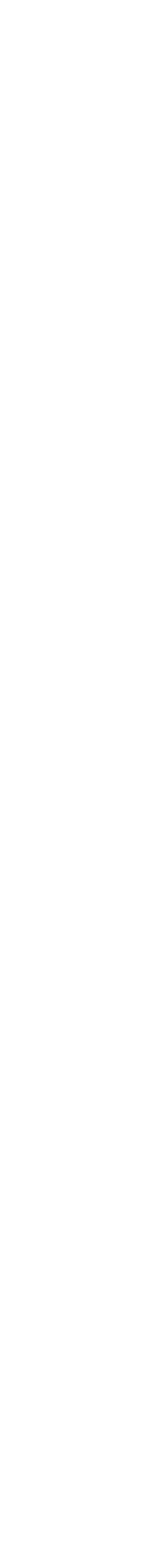

pertumbuhan ekonomi. Manakala pengalaman di Korea Selatan yang dicatatkan oleh Oh (2005) menunjukkan wujudnya hubungan satu arah antara perkembangan pelancongan dengan pertumbuhan ekonomi. Di Taiwan pula kajian oleh Kim, Chen dan Jang (2006) menunjukkan hubungan dua hala antara pelancongan dengan pertumbuhan ekonomi iaitu, keduadua saling menyokong.

\section{Data, Metodologi Kajian dan Keputusan Empirikal}

\section{Data}

Kajian ini mengguna pakai data siri masa yang diambil daripada bahagian Statistik Pelancongan Malaysia Kementerian Pelancongan, World Tourism Organization dan World Development Indicator untuk tempoh 1976-2005. Dalam usaha melihat apakah perkembangan industri pelancongan sebagai perangsang atau penyebab kepada pertumbuhan ekonomi atau sebaliknya, pemboleh ubah penganggar (proxy) digunakan.

Perkembangan industri pelancongan adalah dianggarkan oleh pemboleh ubah bilangan ketibaan pelancong yang dinotasikan sebagai LMSAR, LTHAR, LSGAR, LINAR masing-masing bagi Malaysia, Thailand, Singapura dan Indonesia ${ }^{1}$. Sementara pertumbuhan ekonomi adalah dianggarkan oleh pemboleh ubah Keluaran Dalam Negara Kasar pada harga konstan USD (KDNK) dan dinotasikan sebagai LMSGDP, LTHGDP, LSGGDP dan LINGDP masing-masing untuk pasaran bagi Malaysia, Thailand, Singapura dan Indonesia. Kedua-dua pemboleh ubah adalah dalam bentuk logaritma.

\section{Spesifikasi Model dan Keputusan Empirikal²}

Pra-syarat penting yang perlu dipenuhi dalam menggunakan kaedah kointegrasi Johansen (1988) and Johansen and Juselious (1990)², data mestilah bersifat pegun pada order yang sama. Bagi tujuan tersebut, dalam analisis ini terlebih dahulu ujian kepegunan perlu dilakukan. Setelah prasyarat ini dipenuhi, barulah ujian kointegrasi dapat dilakukan. Ini disusuli pula dengan ujian penyebab Granger bagi tujuan mengenal pasti hala atau arah hubungan antara pemboleh ubah ekonomi yang dikaji.

\section{Unit Root and Ujian Kointegrasi}

Ujian kepegunan data adalah penting apabila data siri masa digunakan dalam analisis ekonomi. Ini bagi tujuan mengelakkan penganggaran yang 'spurious'. Penganggaran yang spurious tidak membawa sebarang makna dan berkemungkinan menyebabkan bias (Engle \& Granger, 1987; Enders, 1995, Song \& Witt, 2000).

Terdapat beberapa ujian formal yang boleh dilakukan untuk mengenal pasti kepegunan data siri masa yang digunakan. Namun, kajian ini menggunakan

IJMS 17 (1), 171-188 (2010) 
ujian Augmented Dickey Fuller, (ADF, 1979). Ujian ADF berasaskan regresi biasa adalah seperti berikut:

$$
\text { Ujian ADF: } \Delta \mathrm{Y}_{\mathrm{t}}=\mathrm{a}_{1}+\delta \mathrm{t}+\beta \mathrm{Y}_{\mathrm{t}-1}+\sum_{\mathrm{Ii}=1}^{\mathrm{P}} \varpi \Delta \mathrm{Y}_{\mathrm{t}-1}+\mathrm{v}_{\mathrm{t}}
$$

Dengan pemboleh ubah $\Delta \mathrm{Y}_{\mathrm{t}-1}$ menunjukkan pembezaan pertama, $\mathrm{V}_{\mathrm{t}}$ adalah ralat penganggaran dan $\alpha, \beta, \delta$, and $\varpi$ adalah parameter yang ingin dianggarkan. Keputusan ujian ADF seperti ditunjukkan dalam Jadual 3.

Jadual 3

Ujian Unit Root pada Peringkat Tingkat (level) dan Perbezaan Pertama

\begin{tabular}{|c|c|c|c|c|c|}
\hline \multirow{3}{*}{ Negara } & & \multicolumn{4}{|c|}{ Penambahan Dickey-Fuller (ADF) } \\
\hline & \multirow{2}{*}{ Pemboleh Ubah } & \multicolumn{2}{|c|}{ Peringkat Tingkat (level) } & \multicolumn{2}{|c|}{ Pembezaan Pertama } \\
\hline & & $\mathrm{T}_{\mu}$ & $\mathrm{T}_{\tau}$ & $\mathrm{T}_{\mu}$ & $\mathrm{T}_{\tau}$ \\
\hline \multirow{2}{*}{ Indonesia } & LINDAR & -1.9093 & -1.1447 & $-3.2915^{* *}$ & $-3.4541^{* *}$ \\
\hline & LINDGDP & -1.5211 & -1.5255 & $-3.7657^{* *}$ & $-3.9807^{* *}$ \\
\hline \multirow{2}{*}{ Malaysia } & LMSAR & -0.0370 & -2.4682 & $-5.3302^{* * *}$ & $-5.2262^{* * *}$ \\
\hline & LMSGDP & -0.5435 & -2.4352 & $-4.0834^{* * *}$ & $-4.0715^{* * *}$ \\
\hline \multirow{2}{*}{ Singapura } & LSGAR & -0.8521 & -1.2929 & $-7.0930^{* * *}$ & $-7.1708^{* * *}$ \\
\hline & LSGGDP & -0.9544 & -1.7088 & $-4.1441^{* * *}$ & $-4.3471^{* * *}$ \\
\hline \multirow{2}{*}{ Thailand } & LTHAR & -1.1447 & -0.5380 & $-4.1781^{* * *}$ & $-4.5692^{* * *}$ \\
\hline & LTHGDP & -1.3293 & -1.6320 & $-2.8021^{*}$ & $-3.5446^{*}$ \\
\hline
\end{tabular}

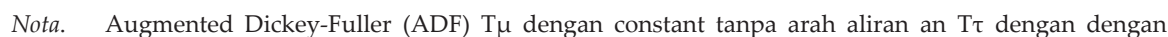
constant danarah aliran.

- Nilai kritikal pada 1\%, 5\% dan 10\% bagi ADF T $\mu$ pada peringkat tingkat ialah -3.6793, - 2.9677 dan -2.6229 .

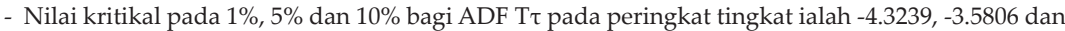
-3.2253 .

- Nilai kritikal pada $1 \%, 5 \%$ dan $10 \%$ bagi ADF T $\mu$ pada peringkat pembezaan pertama ialah $-3.6892,-2.9718$

dan -2.6251

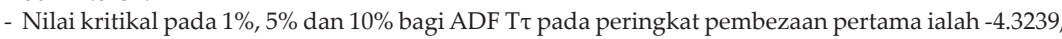
$-3.5806$

dan -3.2253 .

- Penolakan hipotesis dilakukan apabila nilai diperoleh berada di bawah nilai kritikal.

Daripada Jadual 3, kesemua pemboleh ubah yang diuji (dengan memasukkan elemen intersep dan tren) pada peringkat tingkat (level) adalah tidak signifikan pada aras keertian 1\%, 5\% mahupun $10 \%$. Ini bermakna kesemua pemboleh ubah dengan intersep dan tren adalah tidak pegun dan membolehkan kita menyatakan bahawa terdapatnya unit root.

Di jadual yang sama tetapi pada peringkat perbezaan pertama menunjukkan kesemua pembolehubah adalah signifikan sama ada pada 1\%, 5\% ataupun $10 \%$ darjah keertian. Ini membawa maksud data-data bagi kesemua negara

180 IJMS 17 (1), 171-188 (2010) 
yang dipilih adalah pegun pada aras yang sama, iaitu selepas perbezaan pertama. Oleh itu, dikatakan kedua-dua pemboleh ubah perkembangan industri pelancongan dan pertumbuhan ekonomi ini adalah berintegrasi aras pertama dan dinotasikan sebagai I(1).

Dinyatakan berkemungkinan terdapatnya hubungan jangka panjang (kointegrasi) bagi pemboleh ubah-pemboleh ubah yang pegun pada aras yang sama ini. Bagi memastikan kebenaran wujudnya hubungan jangka panjang tersebut, maka ujian perlu dilakukan. Namun, sebelum ujian kointegrasi ini dilakukan, adalah penting terlebih dahulu penentuan lat optimal dilakukan. Pemilihan lat optimal kajian ini adalah menggunakan Akaike Information Criterion (AIC). Berdasarkan kriteria AIC, lat optimal bagi ujian kointegrasi bagi pasaran Malaysia, Thailand, Singapura dan Indonesia masing-masing adalah pada lat 1, 4, 4, 4. Keputusan ujian kointegrasi Johansen pada lat optimal adalah ditunjukkan di Jadual 4 dan 5.

Daripada Jadual 4 , trace $(\lambda$ trace $)$ terdapatnya satu persamaan kointegrasi. Begitu juga pada Jadual 5, trace $\left(\lambda_{\max }\right)$ menunjukkan terdapat satu persamaan kointegrasi antara pemboleh ubah bagi setiap negara. Jelas ujian Johansen memperakukan kewujudan terdapatnya kointegrasi (hubungan jangka panjang) antara pertumbuhan ekonomi dan perkembangan industri pelancongan.

Jadual 4

Johansen dan Juselious Trace $\lambda_{\text {trace }}$-Ujian Satu Persamaan Kointegrasi

\begin{tabular}{|c|c|c|c|c|c|}
\hline \multirow[t]{2}{*}{ Negara } & \multicolumn{2}{|c|}{ Hipotesis } & \multirow{2}{*}{$\begin{array}{c}\text { Trace } \\
\text { Statistik } \\
\left(\lambda_{\text {trace }}\right)\end{array}$} & \multicolumn{2}{|c|}{ Nilai Kritikal } \\
\hline & Но & Alternatif & & $95 \%$ & Kebarangkalian \\
\hline Indonesia & $r=0$ & $\mathrm{r} \geq 1$ & $31.0060^{*}$ & 25.8721 & 0.0105 \\
\hline LINAR-LINGDP & $\mathrm{r} \leq 1$ & $r \geq 2$ & 10.1739 & 12.5180 & 0.1195 \\
\hline Malaysia & $r=0$ & $\mathrm{r} \geq 1$ & $12.8202^{*}$ & 12.3209 & 0.0412 \\
\hline LMSAR-LMSGDP & $\mathrm{r} \leq 1$ & $r \geq 2$ & 1.1399 & 4.1299 & 0.3328 \\
\hline Singapura & $r=0$ & $r \geq 1$ & $20.7402^{*}$ & 18.3977 & 0.0231 \\
\hline LSGAR-LSGGDP & $r \leq 1$ & $r \geq 2$ & 2.3449 & 3.8415 & 0.1257 \\
\hline Thailand & $\mathrm{r}=0$ & $\mathrm{r} \geq 1$ & $20.6684^{*}$ & 18.3977 & 0.0237 \\
\hline LTHAR-LTHGDP & $r \leq 1$ & $\mathrm{r} \geq 2$ & 1.9099 & 3.8415 & 0.1670 \\
\hline
\end{tabular}

Nota: * penolakan hipothesis pada aras $5 \%$.

UjianTracemengenalpastiwujud1 persamaankointegrasipadaaras $5 \%$ darjah keertiaan.

Nota. $\lambda_{\text {trace }}$ menunjukkan rank kointegrasi dikalangan pemboleh ubah. 
Jadual 5

Johansen and Juselious Maximum Eigenvalue $\lambda_{\max }$ - Ujian Satu Persamaan Kointegrasi

\begin{tabular}{lccccc}
\hline Negara & \multicolumn{2}{c}{ Hipotesis } & Trace Statistik & \multicolumn{2}{c}{ Nilai Kritikal } \\
\hline & Ho & Alternatif & $\left(\lambda_{\max }\right)$ & $95 \%$ & Kebarangkalian \\
\hline Indonesia & $\mathrm{r}=0$ & $\mathrm{r}=1$ & $20.8312^{*}$ & 19.3870 & 0.0307 \\
LINAR-LINGDP & $\mathrm{r}=1$ & $\mathrm{r}=2$ & 10.1739 & 12.5180 & 0.1195 \\
Malaysia & $\mathrm{r}=0$ & $\mathrm{r}=1$ & $11.6803^{*}$ & 11.2248 & 0.0416 \\
LMSAR-LMSGDP & $\mathrm{r}=1$ & $\mathrm{r}=2$ & 1.1399 & 4.1299 & 0.3328 \\
Singapura & $\mathrm{r}=0$ & $\mathrm{r}=1$ & $18.3953^{*}$ & 17.1477 & 0.0328 \\
LSGAR-LSGGDP & $\mathrm{r}=1$ & $\mathrm{r}=2$ & 2.3449 & 3.8415 & 0.1257 \\
Thailand & $\mathrm{r}=0$ & $\mathrm{r}=1$ & $18.7584^{*}$ & 17.1477 & 0.0290 \\
LTHAR-LTHGDP & $\mathrm{r}=1$ & $\mathrm{r}=2$ & 1.9099 & 3.8415 & 0.1670
\end{tabular}

Nota: * penolakan hipothesis pada aras $5 \%$.

Ujian Trace mengenalpasti wujud 1 persamaan kointegrasi pada aras $5 \%$ darjah keertian.

Nota. $\lambda_{\max }$ menunjukkan rank kointegrasi dikalangan pemboleh ubah.

\section{Ujian Granger Causality}

Engle and Granger (1987) dan Granger (1988) menyatakan sekiranya terdapat dua pemboleh ubah data siri masa yang berkointegrasi, maka sekurang-kurangnya terdapat hubungan sehala antara kedua-dua pemboleh ubah. Daripada ujian yang telah dilakukan, jelas menunjukkan terdapatnya hubungan jangka panjang antara LMSAR dan LMSGDP, LTHAR dan LTHGDP, LSGAR dan LSGGDP serta LINAR dan LINGDP. Oleh itu, bagi mengetahui arah hubungan penyebab sama ada perkembangan industri pelancongan sebagai penyebab kepada pertumbuhan ekonomi (tourism ledeconomic growth) atau sebaliknya pertumbuhan ekonomi sebagai penyebab perkembangan industri pelancongan (economic growth-led tourism) kajian ini diteruskan dengan melakukan ujian penyebab Granger. Hubungan penyebab antara perkembangan industri pelancongan dan pertumbuhan ekonomi dalam bivariate regression dapat ditunjukkan seperti berikut:

$$
\begin{aligned}
& \Delta L M S A R_{t}=\mu_{2}+\sum_{i=1}^{l} \alpha_{2 i} \Delta L M S A R_{t-1}+\sum_{i=1}^{l} \beta_{2 i} \Delta L M S G D P_{t-1}+e_{2 t} \\
& \Delta L M S G D P_{t}=\mu_{1}+\sum_{i=1}^{l} \alpha_{1 i} \Delta L M S G D P_{t-1}+\sum_{i=1}^{l} \beta_{1 i} \Delta L M S A R_{t-1}+e_{1 t}
\end{aligned}
$$

182 IJMS 17 (1), 171-188 (2010) 


$$
\begin{aligned}
& \Delta \text { LTHAR }_{t}=\mu_{2}+\sum_{i=1}^{l} \alpha_{2 i} \Delta \operatorname{LTHAR}_{t-1}+\sum_{i=1}^{l} \beta_{2 i} \Delta \operatorname{LTHGDP}_{t-1}+e_{2 t} \\
& \Delta \text { LTHGDP }_{t}=\mu_{1}+\sum_{i=1}^{l} \alpha_{1 i} \Delta L T H G D P_{t-1}+\sum_{i=1}^{l} \beta_{1 i} \Delta L T H A R_{t-1}+e_{1 t} \\
& \Delta L S G A R_{t}=\mu_{2}+\sum_{i=1}^{l} \alpha_{2 i} \Delta L S G A R_{t-1}+\sum_{i=1}^{l} \beta_{2 i} \Delta L S G G D P_{t-1}+e_{2 t} \\
& \Delta L S G G D P_{t}=\mu_{1}+\sum_{i=1}^{l} \alpha_{1 i} \Delta L S G G D P_{t-1}+\sum_{i=1}^{l} \beta_{1 i} \Delta L S G A R_{t-1}+e_{1 t} \\
& \Delta L I N A R_{t}=\mu_{2}+\sum_{i=1}^{l} \alpha_{2 i} \Delta L I N A R_{t-1}+\sum_{i=1}^{l} \beta_{2 i} \Delta L I N G D P_{t-1} \\
& \Delta L I N G D P_{t}=\mu_{1}+\sum_{i=1}^{l} \alpha_{1 i} \Delta L I N G D P_{t-1}+\sum_{i=1}^{l} \beta_{1 i} \Delta L I N A R_{t-1}+e_{1 t}
\end{aligned}
$$

Dengan $\mu$ adalah komponen deterministik, $\Delta$ adalah simbol untuk pembezaan, $\mathrm{e}_{\mathrm{t}}$ adalah ralat penganggaran white noise sementara LMSAR, LTHAR, LSGAR dan LINAR adalah perkembangan industri pelancongan sementara LMSGDP, LTHGDP, LSGGDP dan LINGDP adalah pertumbuhan ekonomi.

Dalam sistem kointegrasi, hipotesis nol yang menyatakan perkembangan industri pelancongan tidak atau bukan penyebab Granger pertumbuhan ekonomi tidak dapat ditolak sekiranya $\beta_{11}=\beta_{12}=\ldots \ldots \ldots \ldots . .=\beta_{1 \mathrm{n}}=0$---- (10)

Keadaan yang serupa terhadap hipotesis nol bagi pertumbuhan ekonomi bukan penyebab Granger bagi perkembangan industri pelancongan tidak dapat ditolak sekiranya $\beta_{21}=\beta_{22}=\ldots \ldots \ldots \ldots . .=\beta_{2 n}=0$, ---- (11)

Keputusan ujian penyebab Granger dengan menggunakan ujian F adalah seperti ditunjukkan di Jadual 6. Lat optimal kajian adalah lat 4 bagi Indonesia, Singapura dan Thailand manakala lat 1 bagi Malaysia. Hasil kajian mendapati terdapat hubungan satu hala sahaja antara kedua-dua pemboleh ubah dengan perkembangan industri pelancongan sebagai penyebab kepada pertumbuhan ekonomi (tourism-led economic growth) bagi Malaysia dan Singapura. Hasil kajian ini konsisten dengan dapatan 
kajian oleh Gunduz dan Hatemi (2005) dan Balaguer dan Cantavella-Jorda (2002). Lanjutan hasil kajian menunjukkan setiap satu peratus kenaikan dalam perkembangan industri pelancongan (ketibaan pelancong) akan meningkatkan pertumbuhan ekonomi sekitar $0.08 \%$ dan $0.02 \%$ masingmasing bagi Malaysia dan Singapura. Ini bermakna jika berlaku peningkatan $50 \%$ ketibaan pelancong ke Malaysia dan Singapura pertumbuhan ekonomi di kedua-dua negara ini akan meningkat masing-masing $4 \%$ dan $1 \%$.

Alasan yang boleh diberikan kepada kes Malaysia dan Singapura adalah berkaitan dengan sokongan padu dan penglibatan aktif pihak kerajaan Malaysia dan Singapura terhadap industri pelancongan mereka. Ini kerana secara relatifnya destinasi pelancongan di kedua negara ini agak baru berbanding dengan Thailand dan Indonesia. Selain itu galakan dalam pelbagai bentuk insentif turut diberikan kepada pengusaha swasta untuk melibat diri dan merancakkan perkembangan industri pelancongan serta membolehkan ekonomi negara berkembang dengan lebih pantas. Ciri industri pelancongan yang agak robust dengan persekitaran ekonomi global yang tidak menentu turut memperkukuhkan lagi perkembangan industri ini.

Sementara bagi Indonesia dan Thailand, keadaan adalah sebaliknya iaitu pertumbuhan ekonomi sebagai penyebab kepada pembangunan pelancongan (economic growth-led tourism). Dapatan kajian ini adalah selari dengan dapatan kajian oleh Oh (2005) bagi kes negara Korea.

Sungguhpun tiada alasan kukuh dapat dikemukakan untuk kedua-dua negara, namun keadaan ini berkemungkinan ada kaitannya dengan keadaan struktur ekonomi negara berkenaan. Terdapat sedikit perbezaan dalam kontek tempoh masa pembangunan industri ini berbanding dengan Malaysia dan Singapura. Bagi negara Indonesia dan Thailand mereka mempunyai sejarah yang lebih lama dalam industri ini. Destinasi pelancongan seperti Bali di Indonesia, Bangkok dan Phuket di Thailand telah lama terkenal sebelum Singapura dan Malaysia memajukan industri pelancongan mereka secara intensif. Perbezaan ini memungkinkan wujudnya perbezaan peranan industri pelancongan kepada pertumbuhan - ekonomi di negara negara ini.

Bagi negara yang industri pelancongannya telah pun berkembang maju dan kukuh seperti di Thailand dan Indonesia didapati tidak banyak pembangunan fizikal projek-projek pelancongan yang dapat membantu secara ketara kepada pertumbuhan ekonomi. Sebaliknya perkembangan pesat ekonomi secara keseluruhannya yang membantu pembangunan industri pelancongan. Analisis ini menunjukkan 1\% kenaikan dalam pembangunan ekonomi akan menyebabkan industri pelancongan mengalami pembangunan sebanyak sekitar $0.04 \%$ dan $0.05 \%$ masingmasing bagi Thailand dan Indonesia.

184 IJMS 17 (1), 171-188 (2010) 


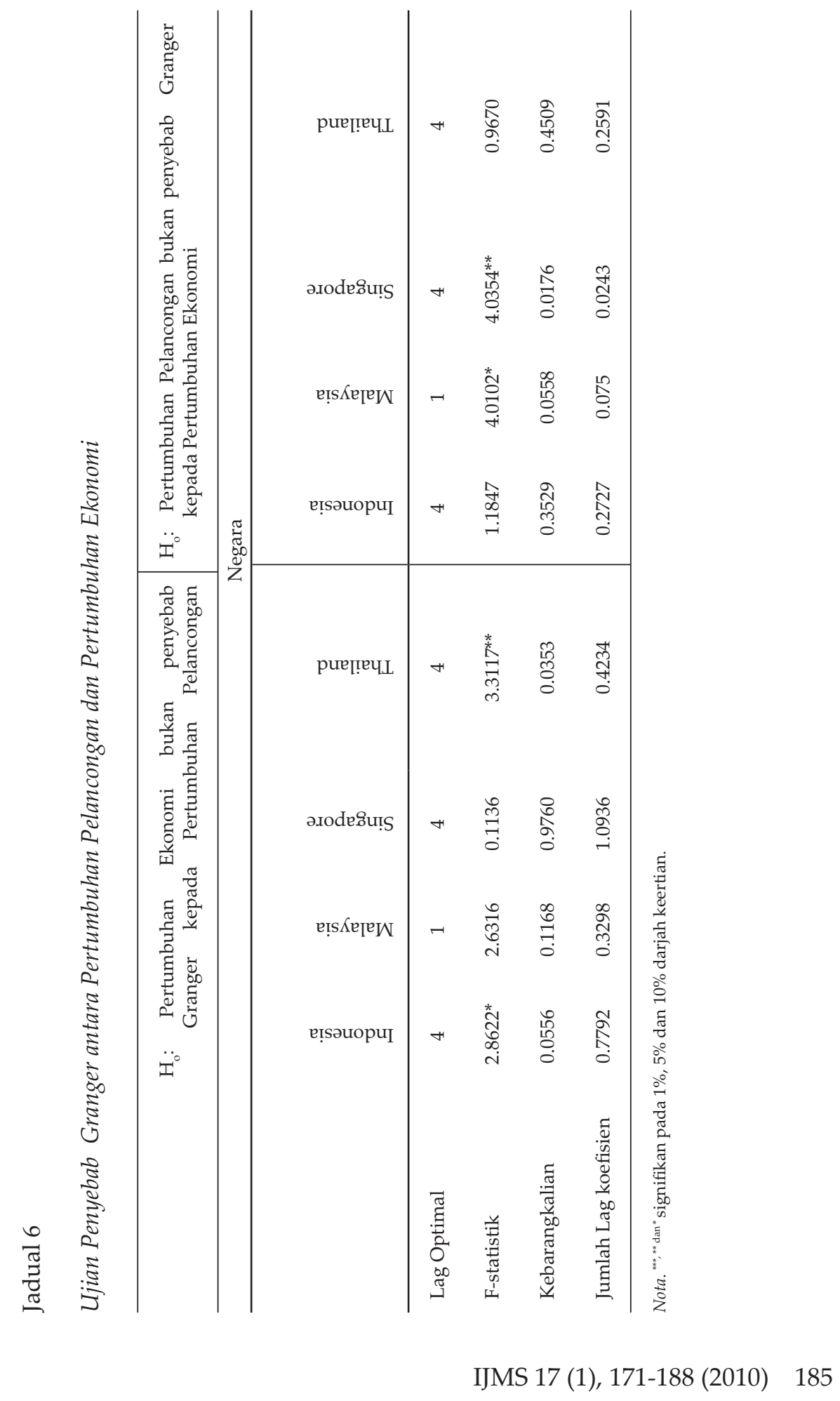




\section{Kesimpulan dan Implikasi Dasar}

Pemakaian kaedah ujian penyebab Granger untuk melihat arah hubungan antara perkembangan industri pelancongan dan pertumbuhan ekonomi di sesebuah negara masih baru. Sejauh ini kajian hanya dilakukan di beberapa buah negara sahaja seperti Sepanyol, Greece, Korea Selatan, Turki dan Taiwan. Hasil kajian mereka adalah berbeza mengikut pengalaman yang dilalui oleh negara masing-masing dalam membangunkan industri pelancongan ini. Dalam konteks kajian ini pula didapati perkembangan industri pelancongan adalah penyebab kepada pertumbuhan ekonomi berlaku di Malaysia dan Singapura. Ini mungkin ada kaitan atau signifikannya dengan tindakan aktif dan agresif pihak kerajaan di keduadua negara membangunkan industri pelancongan masing-masing.

Dari segi dasarnya adalah perlu bagi setiap negara yang ingin menjadikan industri pelancongan sebagai salah satu enjin pertumbuhan ekonomi utama untuk terus membangunkan industri pelancongan di negara masingmasing. Merujuk kembali kepada Malaysia misalnya, pihak kerajaan telah mensasarkan supaya industri pelancongan dijadikan sebagai salah satu industri utama pembekal penting perolehan wang asing. Oleh itu, pelbagai usaha yang bersepadu telah digerakkan bagi merangsang perkembangan industri ini. Pihak kerajaan telah melibat diri secara langsung dalam industri ini disamping menyediakan pelbagai insentif untuk menggalakkan penglibatan pihak swasta. Hasilnya banyak terbina projek-projek pelancongan yang secara langsung memesatkan pertumbuhan ekonomi negara. Oleh itu, kerajaan di negara terlibat perlu membuat penilaian mengenai prospek industri ini di negara mereka dan merangka dasar yang sesuai sama ada industri boleh dimajukan ke tahap yang lebih tinggi untuk menjadi penyumbang penting kepada pendapatan negara khususnya kepada perolehan wang asing.

\section{Nota Akhir}

1. Pertumbuhan pelancongan adalah dianggarkan oleh bilangan ketibaan pelancong sebagaimana kajian oleh Wang \& Godbey (1994). Bagaimanapun penggunaan pendapatan daripada pelancongan juga boleh digunakan sebagai proksi kepada pertumbuhan pelancongan seperti dinyatakan oleh Kim et al. (2005).

2. Pakej statistikal yang digunakan dalam penyelidikan ini EViews 5.0.

3. Cheung dan Ng (1998) menyatakan procedur Johansen adalah lebih efisyen berbanding dengan two-step approach oleh Engle and Granger (1987). Sementara Gonzalo (1994) pula menyatakan prosedur Johansen memiliki finite-sample properties. 


\section{Rujukan}

Ahmed, J., \& Kwan, A.C.C. (1991). Causality between exports and economic growth. Economic Letters, 37, 243-248.

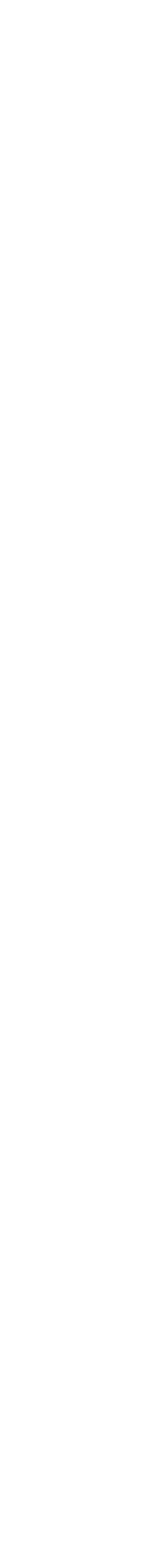

Amaoeteng, K., \& Amoaka-Adu, B. (1996). Economics growth, export and external debt causality: The case of African countries. Applied Economics, 28, 21-27.

Balaguer, L., \& Cantavella-Jorda, M. (2002). Tourism as a long run economic growth factor The spanish case. Applied Economics, 34, 877-884.

Balassa, B. (1977). Exports and economic growth: Further evidence. Journal of Development Economics, 5(2), 181-189.

Borensztein, E., Gregorio, J.D., \& Lee. (1998). How does foreign direct investment affect economic growth? Journal of International Economics, 45, 115-135.

Cheung, Y.W., \& Ng, L.K. (1998). International evidence on the stock market and aggregate economic activity. Journal of Empirical Finance, 5, 281296.

Dalamagas, B. (2000). Public sector and economic growth: The Greek experience. Applied Economics, 32, 277-288.

Demetriades, P.O., \& Hussein, K.A. (1996). Does financial development cause economic growth? Time series evidence from 16 countries (Dept. of Economics Working Paper (No 4)). University of East London.

Dodaro, S. (1993). Exports and growth: A reconsideration of causality. Journal of Developing Areas, 27, 427-431.

Dritakis, N. (2005). Tourism as a long-run economic growth factor: An empirical investigation for Greece using causality analysis. Tourism Economics, 10(3), 305-316.

Enders, W. (1995). Applied econometric time series. New York: Wiley.

Engle R.F., \& Granger, C.W.J. (1987). Cointegration and error correction: Representation, estimation and testing, Econometrica, 55, 251-276.

Esfahani, H.S., (1991). Export, import and economic growth in semi industrialised countries. Journal of Development Economics, 35, 93-116.

Ghali, K.H. (1998). Government size and economic growth: Evidence from a multivariate cointegration analysis. Applied Economics, 31, 975-987.

Gonzalo, J. (1994). Comparison of five alternative methods of estimating long-run equilibrium relationship. Journal of Econometrics, 60, 203-233.

Grossman, D.N. (2003). Growth in government and economic growth: The Australian experience. Australian Economic Papers, 27, 33-43.

Gunduz. L., \& Hatemi, J.A. (2005). Is the tourism-led growth hypothesis valid for Turkey? Applied Economics Letters, 12, 499-504.

Johansen, A., \& Juselious. (1990). Maximum Likelihood estimation and inference on cointegration with application to the demand for money. Oxford Bulletion of Economics and Statistics, 52, 169-209.

IJMS 17 (1), 171-188 (2010) 
Johansen, S. (1988). Statistical analysis of cointegration vectors. Journal of Economic Dynamics and Control, 12, 231-254.

Kim, H.J., Chen, M.H., \& Jang, S.S. (2006). Tourism expansion and economic development: The case of Taiwan. Tourism Management, 27, 925-933.

Liu, X., Burridge, P., \& Sinclair, P.J.N. (2002). Relationships between economic growth, foreign direct investment and trade: Evidence from China. Applied Economics, 34, 1433-1440.

Mohd Azlan Shah Zaidi, Zulkefly Abdul Karim, \& Aminudin Mokhtar. (2003). Pelaburan langsung asing (PLA) dan pertumbuhan ekonomi:

- Bukti Empirikal. ANALISIS 10(2), 223-249.

Murinde, V., \& Eng, F.S (1994). Financial development and economic growth in Singapore: Demand-following or supply-leading? Applied Financial Economics, 4, 391-404.

Oh, C.O. (2005). The contribution of tourism development to economic growth in the Korean economy. Tourism Management, 26, 39-44.

Ram, R. (1986). Government size and economic growth: A new framework and some evidence from cross-section and time-series data. American Economic Review, 76, 190-203.

Shan, J. (2002). A VAR approach to the economics of FDI in China. Applied Economics, 34, 885-893.

Shan, J., \& Sun, F. (1998). On the export-led growth hypothesis: The economic evidence from China. Applied Economics, 30, 1055-1065.

Song, H., \& Witt. S.F. (2000). Tourism Demand Modeling and Forecasting: Modern Econometric Approaches. Amsterdam: Pergamon, .

Statistik Pelancongan Malaysia. (2004). Dirujuk pada 20 Ogos 2005 di http:/ www.tourism.gov.my/ (atas talian).

Thornton, J. (1997). Export and economic growth: Evidence from $19^{\text {th }}$ Century Europe. Economic Letters, 46, 149-158.

Wang, P., \& Godbey, G. (1994). A normative approach to tourism growth to the year 2000. Journal of Travel Research(Summer), 32-37.

World Bank. (2006). World development indicator. (2005). Softcopy Database. World Tourism Organization. (2006). Statistic year book 2006. Spain Madrid. 